\title{
PERSUSUAN (AR-RADHAA') MENJADIKAN KEMAHRAMAN DALAM PERKAWINAN (KAJIAN TAFSIR MAUDU'I ALQURAN SURAT AN-NISA AYAT 23)
}

\author{
Thoat Setiawan \\ Program Studi Hukum Keluarga Pasca Sarjana UIN Sultan Syarif Kasim Riau \\ Jl. HR. Soebrantas 155 Km 15 Simpang Baru Panam Pekanbaru 28293 \\ e-mail: thoatsetiawan07@gmail.com
}

\begin{abstract}
The implementation of marriage in Indonesia has been equipped with regulations regarding the legal requirements of marriage. One of them is the regulation concerening with whether marriage is permitted by a couple of sepersusuan (a couple who belongs to the same breast feeder) since thetre still marriages that are performed by such couples. This study therefore aimed to figure out the status and posistion of marriage a couple of sepersusuan. The problem of the research in this study was formulated in the following question: what is the status and position regarding with the legal consequences of marriage by sepersusuan couples in the framework. of Islamic law. The research method used was Tafsir Maudhu'i Discussion by collecting and systematically compiling the verses and trying to summarize the interpretations of the commentators (interpreters) on the verses of the Qur'an associated with the theme of sepersusuan (ar-Radhaa ') Making it Permitted In Marriage. After that it was described by observing the Munasabah and Asbabun Nuzul of the verses by referring to some of Tafsir al-Munir's primary sources, Tafsir al-Misbah, Tafsir Ibn Katsir.
\end{abstract}

Kata kunci: persusuan (ar-radhaa), hukum Islam, hukum perkawinan

\section{PENDAHULUAN}

H ukum Islam adalah ilmu yang alam sosial dan alam logika $\left(r a^{\prime} y\right)$ sehingga menjadi ilmu yang mapan. Dialektika antara manqul dan $r a^{\prime} y / m a^{\prime} q u l$ dalam konteks sosial itulah yang membuat hukum Islam mengalami dinamika dalam sejarah perkembanganya. Faktor sosial dan konteks pun turut mempengaruhi terjadinya dialektika tersebut karena sejak kemunculanya Islam adalah respon dari situasi sosial. Hukum-hukum Islam pun lahir sebagaian dari respon terhadap kondisi sosial.

Salah satu perkembangan sosial yang terjadi dan yang paling besar mendapatkan perhatian besar dalam hukum Islam adalah masalah hukum keluarga. Ayat-ayat hukum dalam Alquran yang cukup mendetail uraianya dibandingkan dengan persoalan hukum lainya adalah menyangkut hukum keluarga tersebut, seperti pernikahan dan persusuan.

Pernikahan merupakan pelaksanaan hukum agama Islam, maka dalam melaksanakan pernikahan oleh agama ditentukan unsur-unsurnya yang menurut istilah hukumnya disebut dengan rukunrukun. Masing-masing rukun memerlukan syarat-syarat sahnya. Apabila dalam suatu perkawinan tidak memenuhi rukun dan syarat sahnya perkawinan serta adanya penghalang perkawinan, maka perkawinan 
tersebut tidak dapat dilaksanakan. Salah satu yang menyebabkan tidak bisa dilaksanakan perkawinan yaitu apabila diketahui adanya sepersusuan.

\section{METODE PENELITIAN}

Metode penelitian yang dipergunakan dalam penelitian ini adalah Metode Tafsir Maudu'i merupakan metode yang membahas ayat-ayat Alquran sesuai dengan tema atau judul yang telah ditetapkan. Semua ayat yang berkaitan dihimpun, kemudian dikaji secara mendalam dan tuntas dari berbagai aspek yang terkait dengannya, seperti asbab al-nuzul, kosakata, dan sebagainya. Semua dijelaskan dengan rinci dan tuntas, serta didukung oleh dalil-dalil atau faktafakta yang dapat dipertanggungjawabkan secara ilmiah, baik argumen yang berasal dari Alquran, Hadis, maupun pemikiran rasional. (Nashruddin, 1998: 151) Dengan menggunakan beberapa tahapan diantaranya (Abd al-Havy al-Farmawi, 1977: 52) :

1. Menetapkan masalah yang akan dibahas

2. Menghimpun seluruh ayat-ayat Alquran yang berkaitan dengan masalah tersebut

3. Menyusun urut-urutan ayat terpilih sesuai dengan perincian masalah dan atau masa turunnya, sehingga terpisah antara ayat Makkiyah dan Madaniyah. Hal ini untuk memahami unsur pentahapan dalam pelaksanaan petunjuk-petunjuk Alquran.

4. Mempelajari/memahami korelasi (munasabat) masing-masing ayat dengan surah-surah di mana ayat tersebut tercantum (setiap ayat berkaitan dengan tema sentral pada suatu surah).

5. Melengkapi bahan-bahan dengan hadis-hadis yang berkaitan dengan masalah yang dibahas.

6. Menyusun outline pembahasan dalam kerangka yang sempurna sesuai dengan hasil studi masa lalu, sehingga tidak diikutkan hal-hal yang tidak berkaitan dengan pokok masalah

7. Mempelajari semua ayat yang terpilih secara keseluruhan dan atau mengkompromikan antara yang umum dengan yang khusus, yang mutlak dan yang relatif, dan lain-lain sehingga kesemuanya bertemu dalam muara tanpa perbedaan atau pemaksaan dalam penafsiran

8. Menyusun kesimpulan penelitian yang dianggap sebagai jawaban Alquran terhadap masalah yang dibahas.

\section{PEMBAHASAN}

\section{Ayat-ayat Persusuan (ar-Radhaa')}

Allah Swt dalam Alquran menampilkan ayat-ayat yang mengkaji tentang persusuan (ar-Radhaa') dengan aneka derivasinya. Di surat al-Baqarah ayat 233 Allah menggunakan kata kerja

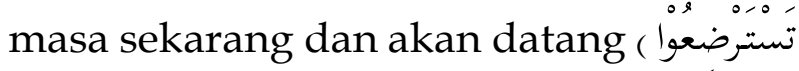

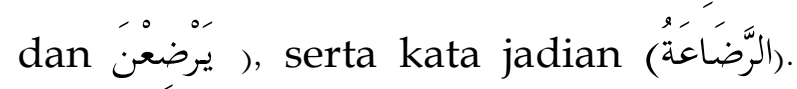
Surat an-Nisa ayat 23 muncul kata kerja masa lampau (أَرضَعْنَ) dan kata jadian Surat al-Hajj ayat 2 terlihat lafal isim fa'il (مرضْعَة) juga kata kerja masa

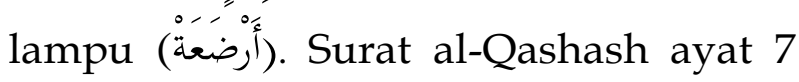
datang dengan kata kerja perintah اسم مكان dan nama tempat plural (أَرضعبْن) 


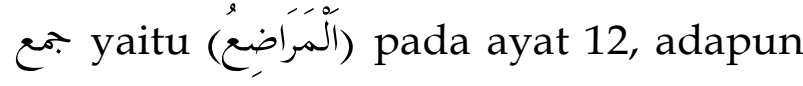
di surat al-Thalaq ayat 6 terpilih langgam kata kerja lampau (ارضعن) juga masa sekarang dan akan datang yaitu (ترضُ).

Uraian ayat-ayat yang menuturkan persusuan (ar-Radhaa') sebagai berikut:

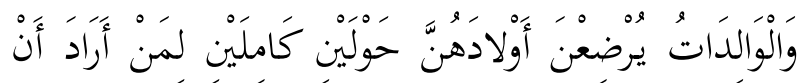

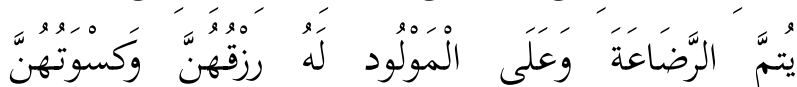
"ِ بالمعروف لا لا تكلف نفس إلا وسعها لا تضار والده

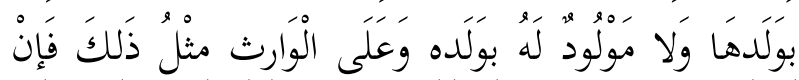

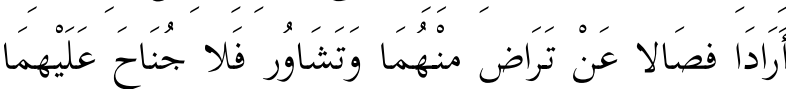

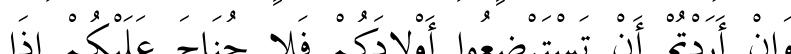

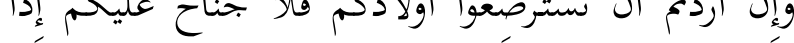

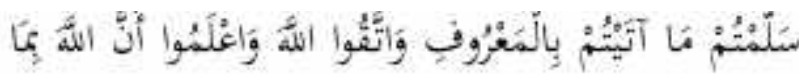

$$
\text { تعملون بصير ( البقرة :سبr) }
$$

Para ibu hendaklah menyusukan anakanaknya selama dua tahun penuh, yaitu bagi yang ingin menyusui secara sempurna. Dan kewajiban ayah memberi makan dan pakaian kepada para ibu dengan cara ma'ruf. Seorang tidak dibebani lebih dari kesanggupannya. Janganlah seorang ibu menderita karena anaknya dan jangan pula seorang ayah menderita karena anaknya. Ahli waris pun berkewajiban seperti itu pula. Apabila keduanya ingin menyapih (sebelum dua tahun) dengan persetujuan dan permusyawaratan antara keduanya, maka tidak ada dosa atas keduanya. Dan jika kamu ingin menyusukan anakmu kepada orang lain, maka tidak ada dosa bagimu memberikan pembayaran menurut yang patut. Bertakwalah kamu kepada Allah dan ketahuilah bahwa Allah Maha melihat apa yang kamu kerjakan. (Q.S. al-Baqarah [2]: 233)

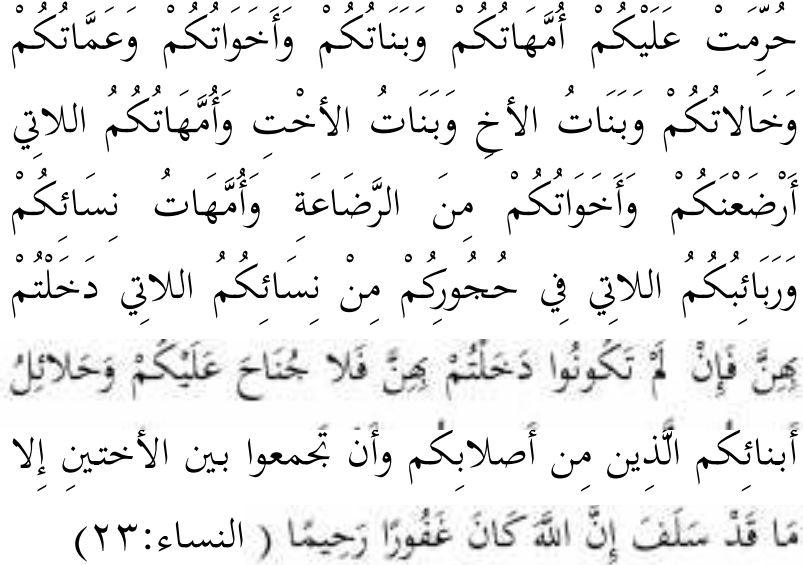

Diharamkan atas kamu (menikahi) ibuibumu, anak-anakmu yang perempuan, saudara-saudaramu yang perempuan, saudara-saudara ayahmu yang perempuan, saudara-saudara ibumu yang perempuan, anak-anak perempuan dari saudarasaudaramu yang laki-laki, anak-anak perempuan dari saudara-saudaramu yang perempuan, ibu-ibumu yang menyusui kamu, saudara-saudara perempuanmu sesusuan, ibu-ibu istrimu (mertua), anakanak perempuan dari istrimu (anak tiri) yang dalam pemeliharaanmu dari istri yang telah kamu campuri, tetapi jika kamu belum campur dengan istrimu itu (dan sudah kamu ceraikan), maka tidak berdosa kamu menikahinya, (dan diharamkan bagimu) istri-istri anak kandungmu (menantu), dan diharamkan mengumpulkan (dalam pernikahan) dua perempuan yang bersaudara, kecuali yang telah terjadi pada masa lampau. Sesungguhnya Allah Maha Pengampun lagi Maha Penyayang. (Q.S. an-Nisa [4]: 23). 


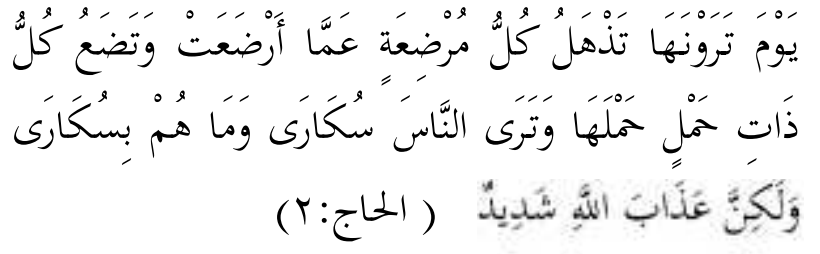

"(Ingatlah) pada hari ketika kamu melihat guncangan itu, semua perempuan yang menyusui anaknya akan lalai terhadap anak yang disusuinya, dan setiap perempuan yang hamil akan keguguran kandungannya, dan kamu melihat manusia dalam keadaan mabuk, padahal sebenarnya mereka tidak mabuk, tetapi azab Allah itu sangat keras".(Q.S. al-Hajj [22]: 2).

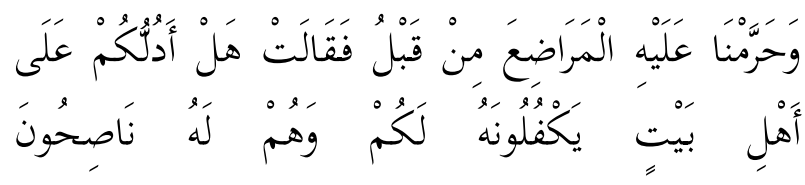

(القصص:r ( )

"Dan Kami cegah dia (Musa) menyusu kepada perempuan-perempuan yang mau menyusui(nya) sebelum itu; maka berkatalah dia (saudara Musa), "Maukah aku tunjukkan kepadamu, keluarga yang akan memeliharanya untukmu dan mereka dapat berlaku baik padanya". (Q.S. alQashash [28]: 12).

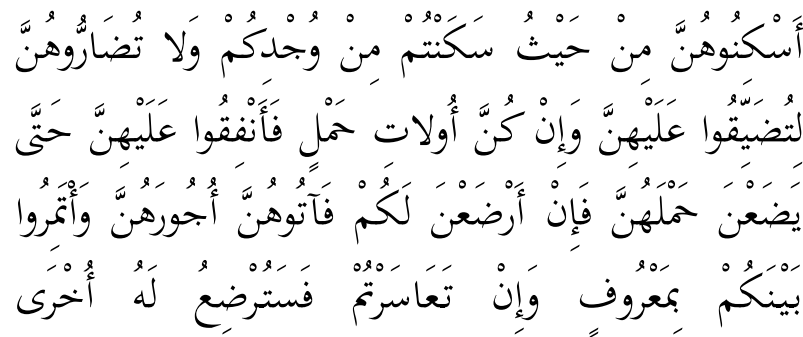

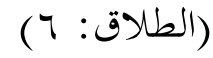

"Tempatkanlah mereka (para istri) di mana kamu bertempat tinggal menurut kemampuanmu dan janganlah kamu menyusahkan mereka untuk menyempitkan (hati) mereka. Dan jika mereka (istri-istri yang sudah ditalaq) itu sedang hamil, maka berikanlah kepada mereka nafkahnya sampai mereka melahirkan kandungan, kemudian jika mereka menyusukan (anakanak)mu maka berikanlah imbalannya kepada mereka; dan musyawarahkanlah di antara kamu (segala sesuatu) dengan baik; dan jika kamu menemui kesulitan, maka perempuan lain boleh menyusukan (anak itu) untuknya". (Q.S. at-Thalaq [65]: 6).

Ayat-ayat tersebut memerlukan perhatian serius dari para akademisi muslim. Namun, penulis akan memusatkan kajian pada ayat 23 surat anNisa' karena keterbatasan ilmu penulis, meskipun tidak menutup kemungkinan ayat lainya juga akan mendapat kajian yang lainya. Ayat yang penulis maksud yaitu:

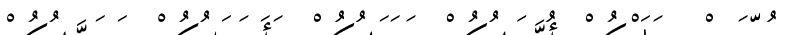

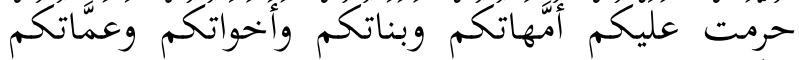

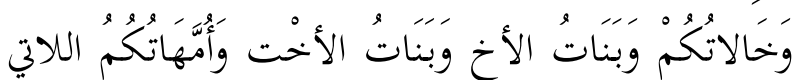

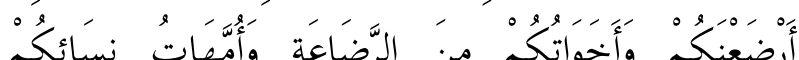

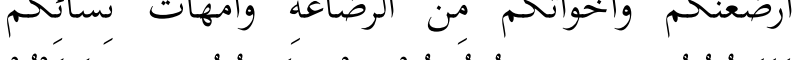

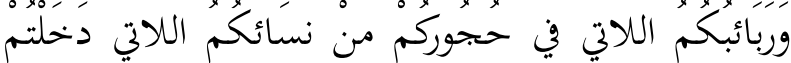

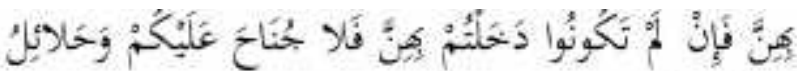

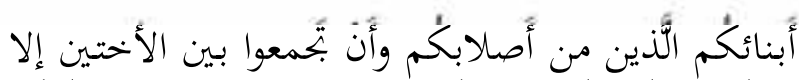

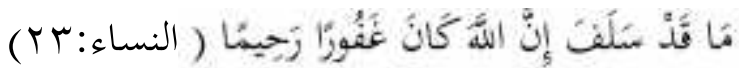
"Diharamkan atas kamu (menikahi) ibuibumu, anak-anakmu yang perempuan, saudara-saudaramu yang perempuan, saudara-saudara ayahmu yang perempuan, saudara-saudara ibumu yang perempuan, anak-anak perempuan dari saudarasaudaramu yang laki-laki, anak-anak perempuan dari saudara-saudaramu yang perempuan, ibu-ibumu yang menyusui kamu, saudara-saudara perempuanmu sesusuan, ibu-ibu istrimu (mertua), anakanak perempuan dari istrimu (anak tiri) yang dalam pemeliharaanmu dari istri yang telah kamu campuri, tetapi jika kamu belum campur dengan istrimu itu (dan sudah 
kamu ceraikan), maka tidak berdosa kamu menikahinya, (dan diharamkan bagimu) istri-istri anak kandungmu (menantu), dan diharamkan mengumpulkan (dalam pernikahan) dua perempuan yang bersaudara, kecuali yang telah terjadi pada masa lampau. Sesungguhnya Allah Maha Pengampun lagi Maha Penyayang". (Q.S. an-Nisa [4]: 23).

\section{Sabab al-Nuzul}

حدثني نمل بن عبد القه المخرمي, قال: ثنا قراد, قال: ابن عيينة, عن عمرو , عن عكرمة, عن ابن عباس رضي الله تعالى عنهما قال: كان أهل الجاهلية يحرمون ما يحرم

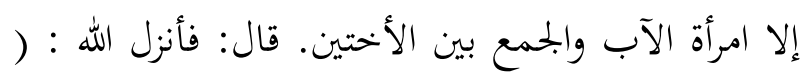

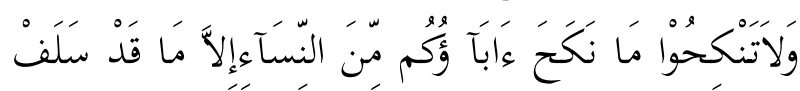

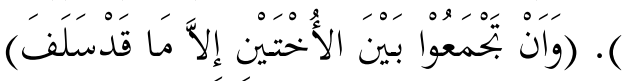

"Muhammad ibn Abdillah alMukharramiy menginformasikan, Qurad memberitahukan kami, Ibn Uyainah menceritakan kepada kami, dari Ikrimah dari Ibn Abbas r.a., ia berkata: Orangorang jahiliyah mengharamkan perempun yang mereka inginkan kecuali ibu tiri dan menikahi dua perempuan bersaudara. Ibn Abbas berkata: maka Allah menurunkan, "Dan jangan kamu menikahi wanita wanita yang telah dinikahi oleh ayahmu, kecuali (kejadian) pada masa yang lalu (lampau), dan diharamkan bagimu mempoligami dua wanita bersaudara, kecuali (kejadian) pada masa yang telah lampau". (Muhammad Ibn Ja`rir, 2001: 549)

\section{Korelasi Ayat}

Allah Swt sebelumnya menjelaskan hukum menikahi anak yatim, jumlah perempuan yang boleh dinikahi dengan syarat mampu berlaku adil dan memberi nafkah, berpesan untuk mempergauli istri dengan baik, memberi teguran keras terhadap orang yang menarik maskawin mereka tanpa alasan yang dibenarkan agama, kemudian Dia melanjutkan keterangan disini dengan menyebut beberapa perempuan yang tidak boleh dinikahi karena unsur kekeluargaan perbesanan atau persusuan. (Wahbah alZuhaili, 2009: 646)

\section{Pengertian Persusuan (ar-Radla')}

Dari segi etimologi persusuan (arRadla') merupakan kata jadian dari hasil derivasi kata kerja masa lampau (fi'il

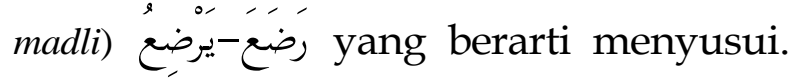
Makna ini terambil dari الَّلَدَأُمَه:

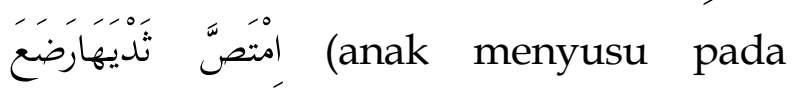
ibunya: mengisap susu ibunya, manusia atau binatang). (Luwis Ma'luf, 1956: 265) Maka arti persusuan (ar-Radla') menyedot puting, baik hewan maupun manusia. Dalam pengertian etimologis tidak dipersyaratkan bahwa yang disusui itu (arRadhi') berupa anak kecil (bayi) atau bukan.

Ruang lingkup sebuah makna sebuah kata secara etimologi lebih luas dari makna terminologi. Pada saat sebuah kata menghendaki kedua makna itu, ahli mengedepankan arti terminologi kecuali ada indikasi yang menariknya kepada arti awal (etimologi). Mengutamakan arti terminologi dari etimologi dikala demikian akan meminimalisir kegaduhan dan kerancauan pikiran, seperti apa yang dialami oleh Imam Bukhariy ketika memfatwakan dampak 
hukum persusuan dua anak pada seekor kambing. Menurut Imam Bukhari, pemberlakuan hubungan persusuan tidak hanya untuk manusia tapi berlaku juga bagi yang mengisap air susu binatang. (Mahmud al-Alusiy, t. Th: 253)

Sementara menurut terminologi, terdapat aneka definisi yang ditampilkan oleh para ahli hukum dari berbagai aliran. Pendapat ini ternyata akan melahirkan konsekuensi hukum, yang pada akhirnya nanti menimbulkan perbedaan pemikiran dalam masalah persusuan.

Dalam pandangan aliran Hanafiyah, persusuan menurut syara' adalah mengisap susu perempuan meskipun dia masih gadis, mati, menopaus. Termasuk arti mengisap, memasukkan air susu ke kerongkongan (al-Wajur) dan melalui hidung (al$\left.S a^{\prime} u t h\right)$, pada waktu tertentu yaitu dua tahun setengah menurut Abu Hanifah dan cukup dua tahun menurut dua santrinya (Abu Yusuf dan Muhammad al-Syaibaniy), pendapat ini lebih tepat. (Muhammad, 2002: 202)

Aliran Malikiyyah berpendapat, persusuan menurut syara' adalah sampainya air susu perempuan meskipun ia sudah mati atau masih kecil yang belum pantas bersetubuh ke kerongkongan anak yang disusui, sekalipun masuk melalui hidung (sa'uth') atau melalui lubang pantat (Huqnah), dengan syarat mengenyangkan. (Ahmad Ibnu Muhammad al-Dardir, 1999: 338)

Aliran Syafi'yyah selanjutnya memuat, persusuan menurut syara' adalah sampainya air susu perempuan tertentu kerongga anak tertentu dengan cara tertentu pula. Perempuan tertentu dalam bahasan ini adalah perempuan yag masih hidup dan berusia minimal sembilan tahun. Sementara maksud dari anak tertentu adalah anak yang masih hidup dan berusia kurang dua tahun. Kata cara tertentu, bermakna ukuran minimal si anak menyusu pada seorang perempuan.

Sedangkan menurut pendapat Aliran Hanabilah berpendapat, persusuan menurut syara' adalah mengisap air susu perempuan yang bisa hamil oleh anak yang berusia kurang dua tahun, atau meminumnya dan lainlain. (Shalih Ibn Ibrahim al-Baliha, 1406: 837)

Ibn Hazm berpendapat, penyusuan secara syara' adalah air susu yang diisap oleh anak dari puting perempuan yang menyusui dengan mulutnya saja.

Mencermati pengertian diatas ada tiga unsur batasan sehingga bisa disebut ar-Radhaa" al-Syar'iy (persusuan yang memiliki efek hukum agama). Pertama, air susu perempuan (لبن أدمية), kedua,air susu itu masuk ke rongga seorang bayi dan ketiga, bayi tersebut belum berusia dua tahun (2ون menurut selain Ibn Hzm.

\section{Makna Global}

Pada ayat-ayat terdahulu disebutkan adanya restu untuk menikahi wanita-wanita yang disenangi dua, tiga, atau empat. Restu untuk menikahi wanita-wanita yang disenangi, lantas dikecualikan, ada yang berkaitan dengan menikahi wanitawanita yang selama ini oleh adat dibenarkan dan itulah yang antara lain 
diuraikan oleh ayat-ayat yang lalu. Dalam ayat ini dan ayat-ayat berkutnya akan dijelaskan wanita-wanita yang tidak boleh dinikahi, meskipun larangan tersebut bukan lahir karena ia dipraktekkan dalam masyarakat, tetapi karena ia tidak sejalan dengan naluri manusia yang sehat. Dari sini dapat dimengerti mengapa larangan ayat yang lalu tidak digabungkan dalam kelompok ayat ini. Di samping itu untuk menggaris bawahi betapa buruknya kebiasaan yang mereka praktekkan itu. (Ibrahim Ibnu Umar alBiqa'iy, t.th: 227)

Setelah Allah Swt menguraikan tujuh macam wanita yang haram dinikahi dari segi hubungan keturunan, selanjutnya diuraikan yang haram dinikahi karena adanya faktor-faktor ekstern yang dimulai penyebutanya dengan ibu-ibu kamu yang menyusui kamu. Karena ia sama dengan ibu dari segi menyusukan, sehingga semua perempuan yang pernah menyusui seorang anak dengan penyusuan yang memenuhi standar yang ditetapkan Allah dan Rasul-Nya, maka dia sama dengan ibu kandung. Demikian juga haram dinikahi semua perempuan yang berhubungan keibuan dengan ibu susu itu, baik karena keturunan atau penyusuan. Sebagaimana haram juga menikahi saudara-saudara perempuan sepersusuan, yaitu perempuan yang mengisap air susu dari ibu yang sama dengan yang kamu isap, baik sebelum, bersamaan atau sesudah kamu mengisapnya. (Muhammad Ibn Ahmad Ibn Abi, 2006: 179)

Allah juga melarang menikahi dari segi hubungan keturunan yaitu dengan saudara-saudara bapak kamu yang perempuan; yakni semua wanita yang mempunyai hubungan dengan bapak dari segi asal usul kelahiran ibunya baik ibu bapak, maupun hanya salah satunya, demikian halnya dengan saudara-saudara ibu kamu yang perempuan dari saudara-saudara kamu yang laki-laki; sekandang atau tidak, demikian juga anak-anak perempuan dari saudara-saudara kamu yang perempuan; itulah yang haram dinikahi dari segi hubungan keturunan. (Muhammad Ibn Ahmad Ibn Abi, 2006: 390)

Ayat yang lalu menunjukan bahwa wanita yang haram dinikahi dari segi hubungan persusuan adalah ibu dan saudara persusuan. Menurut al-Razi berpendapat, posisi hadis yang menjelaskan wanita yang tidak boleh dinikahi sebab persusuan bukan sebagai penjelas (mubayyin) Alquran, akan tetapi sebagai penguat (mu'akid). Allah telah menegaskan dalam ayat persusuan keharaman ibu dan saudara perempuan, tapi keharaman ini tidak terbatas untuk mereka saja. Ketika Allah menamakan ibu, bagi wanita yang menyusui dan saudara untuk anak dari ibu itu sungguh Dia telah memberi peringatan bahwa Dia ingin memberlakukan persusuan seperti keturunan. Allah mengharamkan pernikahan dari segi keturunan tujuh wanita, dan dari tujuh karena faktor kelahiran yaitu ibu dan anak dan sisanya karena persaudaraan. Pada saat Allah mulai menerangkan persusuan, dia hanya menyebutkan satu model dari setiap faktor tadi (ibu dari sisi kelahiran dan saudara dari persaudaraan). Dua contoh yang Allah tmpilkan ini (ibu dan 
saudara), bukti nyata persamaan antara persusuan dengan keturunan. (Muhammad Ibn Umar, 2002: 643

Redaksi ayat ini ditujukan kepada lelaki, kendati demikian ia juga secara terbalik ditujukan kepada wanita. Pada saat ayat ini berkata kepada anak lakilaki diharamkan bagimu menikahi ibu susuan, maka pada saat itu juga ia mengandung pesan kepada anak wanita bahwa diharamkan bagi kamu menikahi bapak susuan (suami dari ibu susuan). (Tafsir al-Munir fi al-aqidah wa asySyari ah wa al-Manhaj, 1991: 390). Tidak disebutkanya wanita secara redaksional, bukan saja karena kebiasaan Alquran menggunakan redaksi yang menunjuk pada lelaki untuk kedua jenis kelamin, tetapi kali ini, boleh jadi juga untuk mengisyaratkan bahwa pada umumnya pernikahan didahului oleh sikap aktif lelaki menampakan keinginan dan melamar perempuan. (Qurais Shihab, 2002: 392)

Para sarjana Islam menegaskan bahwa pernikahan antara keluarga dekat dapat melahirkan anak cucu yang lemah jasmani dan ruhani. Ini bersumber dari keterangan yang disandarkan kepada Rasulallah Saw: "Janganlah kalian menikah dengan keluarga dekat, karena akan lahir anak yang lemah". (H.R. Ibrahim al-Harbiy) (Muhammad Ibn Muhammad alGhazaliy, t.th: 42)

Menurut sementara pakar, belakangan ini ditemukan secara ilmiah bahwa pernikahan antara kerabat yang dekat berpotensi menyebabkan keturunan mudah terjangkit penyakit, cacat fisik, serta tingkat kesuburan yang rendah bahkan bisa mendekati kemandulan. (Muhammad Mutawalli al-Sya'rawiy, t,th: 2094)

Selanjutnya ada juga yang meninjau larangan tersebut dari segi kaharusan menjaga hubungan kekerabatan agar tidak menimbukan perselisihan/perceraian, seperti yang dapat terjadi antara suami istri. Hubungan suami istri tidak selamanya harmonis, ia dapat keruh dan kacau. Bagaimana jadinya jika anak yang seharusnya menyayangi saudara justru bertengkar, bagaimana jadinya jika ayah dan ibu yang semestinya dihormati justru dilecehkan. Pada akhirnya larangan menikahi kerabat boleh jadi untuk memperluas kekerabatan dan mempererat hubungan antra kerabat satu keluarga dengan kerabat keluarga yang lain dalam rangka mengukuhkan satu masyarakat. (Muhammad Mutawalli al-Sya'rawiy, t, th: 2095)

\section{Syarat-syarat Persusuan (ar-Radla')}

Menurut jumhur ulama, syarat persusuan (ar-Radla'), yaitu:

1. Air susu harus berasal dari manusia (لبن الأدمية). Dalam hal ini seseorang itu sudah mempunyai suami atau tidak lagi mempunyai suami. (Abu Bakar Ibn Masud al-Kasaniy, 1986: 8)

2. Air susu itu masuk ke dalam lambung bayi (وصول إلي جوف طفل) baik melalui isapan langsung dari puting payudara maupun melalui alat penampung susu seperti gelas, botol dan lain-lain. Menurut mazhab empat terjadinya persusuan (ar-Radla') tidak harus melalui penyedotan pada puting susu, namun pada sampainya ASI pada 
lambung bayi yang dapat menumbuhkan tulang dan daging. Namun mereka berbeda pendapat mengenai jalan lewatnya ASI, menurut Imam Malik dan Hanafi harus melalui rongga mulut, sedangkan menurut Hambali adalah sampainya pada lambung dan pada otak besar. (Abu Bakar Ibn Masud al-Kasaniy, 1986: 8)

3. Proses persusuan melalui mulut atau hidung. Mayoritas ulama' era terdahulu termasuk Abu Hanifah, Malik Syafi'i, Ahmad, dan lainya memahami kata persusuan (arRadla') dalam arti masuknya air susu ke dalam rongga tubuh anak melalui kerongkonganya atau selain kerongkongan dengan jalan mengisap atau bukan. Karena itu memasukkan air susu, misalnya dengan sendok ke kerongkongan yang dalam bahasa hukum dinamai al-wujur tercakup juga dalam kata menyusukan, sehingga mengakibatkan dampak hukum di atas. Bahkan ada pakar hukum yang memasukkan kata al-sa'uth dalam cakupan kata menyusukan, yaitu memasukkan air susu melalui hidung. Menurut imam Malik, dampak hukum dapat timbul melalui al-Huqnah, yaitu memasukkan air susu melalui lubang pantat dengan jalan suntikan yang akan mengenyangkan. Demikian pula meneteskan air susu pada mata, telinga, atau luka dipersamakan dengan al-Huqnah jika mengenyangkan. Mayoritas ulama menolak dengan tegas pendapat ini, karena memasukkan air susu dengan jalan suntikan dan sejenisnya bagaimanapun juga tidak dinamakan menyusukan. (Abu Bakar Ibn Masud al-Kasaniy, 1986: 9)

4. Tidak ada campuran lain, jika ada campuran dari benda cair atau padat dan air susu tetap mendominasi berlakulah keharaman persususan. Namun, jika campuranya yang 0mendominasi, otomatis dampak hukum tiada berlaku.

5. Bayi tersebut belum berusia dua tahun (دون الحولين) Menurut mazhab fiqh empat dan jumhur ulama, susuan itu harus dilakukan pada usia anak sedang menyusu. Oleh sebab itu, menurut mereka apabila yang menyusu itu adalah anak yang sudah dewasa di atas usia dua tahun, maka tidak ada keharaman untuk menikah sesama susuan.

6. Kadar penyusuan sebanyak lima kali atau lebih secara terpisah, menurut aliran Syafi'i dan Hanbali. Seandainya seorang anak berhenti menyusu untuk menarik nafas, istirahat, karena bosan, berpindah dari satu puting ke puting lainya atau dari seorang perempuan ke perempuan lainya, lantas seketika itu ia kembali menetek, maka semuanya terhitung satu kali. Jika seorang anak menyusu kurang lima kali, atau timbul keraguan berapa kali ia menyusu, dampak hukum keharaman belum terwujud Mereka mengajukan argumentasi sebagai berikut:

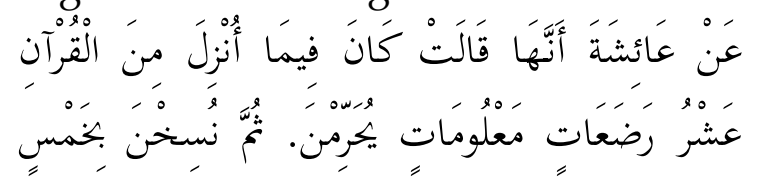




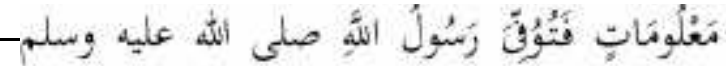

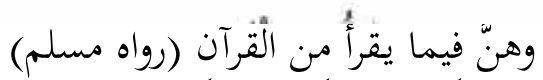

“A'isya r.a berkata: Dahulu Alquran turun menyebutkan sepuluh kali penyusuan yang diyakini dapat mengharamkan, kemudian ketentuan itu dihapus dengan lima kali penyusuan yang diyakini. Rasulallah Saw mangkat dan ayat itu terbaca karena bagian dari Alquran". (H.R. Muslim)

\section{Rukun Persusuan (ar-Radla $\left.>^{\prime}\right)$}

1. Anak yang menyusu (ألرضيع)

2. Perempuan yang menyusui (المرضعة)

3. Kadar air susu (مقدار اللبن)

\section{Sumber Ketetapan Persusuan (ar- Radla')}

Untuk menghindari kesimpang siuran dalam menetapkan seorang anak benar-benar disusui oleh seorang wanita selain ibunya, ulama fiqh menetapkan bahwa perlu alat bukti untuk menetapkan hal tersebut sebagai berikut:

\section{Ikrar (Pengakuan)}

Ikrar yaitu pengakuan persusuan dari pihak laki-laki dan wanita secara bersama atau salah satu dari mereka. Apabila ikrar itu dilakukan sebelum menikah, maka keduanya tidak boleh menikah dan apabila mereka telah menikah maka akad batal.

Imam Hanafi berpendapat, ikrar dalam persusuan adalah pengakuan persusuan dari pihak laki-laki dan wanita secara bersama atau salah satu dari mereka. Apabila ikrar itu dilakukan sebelum menikah, maka keduanya tidak boleh menikah dan apabila mereka menikah maka akad batal. Apabila ikrar itu dilakukan setelah perkawinan, maka mereka harus berpisah. Ketika mereka memilih enggan untuk berpisah, maka hakim berhak memaksa mereka untuk berpisah.

Imam Maliki berpendapat, ar-radaah (menyusui) dapat terjadi dengan adanya ikrar kedua pasangan suami istri secara bersama, atau pemberitahuan salah satu dari orang tua mereka berdua, atau hanya dengan pemberitahuan dari suami yang mukallaf meskipun dilakukan setelah akad, atau pemberitahuan dari seorang istri yang sudah baligh dan dilakukan sebelum akad.

Imam Syafi'i menetapkan bahwa ikrar harus dilakukan oleh dua orang laki-laki karena dianggap lebih unggul dalam ikrar.

\section{Persaksian (al-Baiyyinah)}

Yaitu kesaksian yang dikemukakan orang yang mengetahui secara pasti bahwa laki-laki dan wanita itu sepersusuan. Adapun jumlah saksi yang disepakati ulama fiqh yaitu minimal dua orang saksi laki-laki atau satu orang laki-laki dengan dua orang wanita. Akan tetapi ulama fiqh berbeda pendapat tentang kesaksian seorang laki-laki atau seorang wanita atau empat orang wanita.

Menurut ulama mazhab Hanafi kesaksian tersebut tidak dapat diterima karena 'Umar bin Khattab mengatakan, "Saksi yang diterima 
dalam masalah susuan hanyalah persaksian dua orang laki-laki." Para sahabat lain tidak membantah ketetapan Umar bin Khattab ini, karenanya menurut mereka, ketetapan ini menjadi ijma' para sahabat, dan ijma' para sahabat dapat dijadikan sandaran hukum. Alasan lain yang mereka kemukakan adalah firman Allah Swt dalam Surat al-Baqarah ayat 282 yaitu:

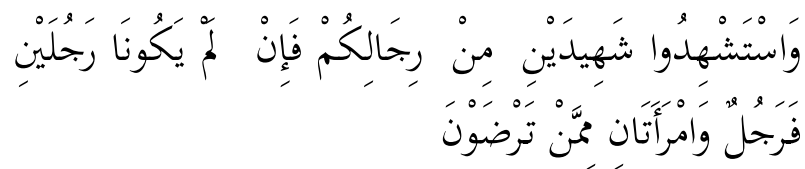

"Dan persaksikanlah dengan dua orang saksi dari orang laki-laki (diantaramu). jika tak ada dua orang laki-laki, maka boleh seorang lelaki dan dua orang perempuan dari saksi-saksi yang kamu ridhoi". (Q.S. al-Baqarah [2]: 282)

Sebagian ulama mengatakan bahwa untuk terjadinya persusuan yang mengakibatkan kemahraman, maka harus ada saksi. Seperti pendapat Ash-Sharabshi, Thawuz, Zuhri, Ibnu Dzi'ib, Auza'i, dan salah satu riwayat Ahmad.

\section{PENUTUP}

Sesuai dengan permasalahan yang menjadi objek penelitian dalam kajian penelitian ini, penulis ingin menyampaikan beberapa kesimpulan:

1. Hukum Islam mengharamkan menikah karena sebab hubungan persusuan, mencakup keharaman menikahi wanita yang menyusui, anak kandung, cucu, ibu, ayah, dan nenek dari wanita yang menyusui, juga haram pula terhadap menikahi saudara sepersusuan dan adik-adik saudara sepersusuan.

2. Seberapa kadar susu yang diminum oleh anak hingga menjadi hubungan susuan menurut Imam Malik dan Abu Hanifah seberapapun banyaknya jika minumnya dibawah umur dua tahun maka terjadi hubungan susuan, menurut Jumhur ulama lebih dari lima kali susuan.

3. Usia anak yang menyusu menurut Jumhur Ulama adalah dibawah umur dua tahun, begitu pula pendapat Imam Abu Hanifah, sedangkan menurut Ulama Zhahiriy anak yang menyusu diatas dua tahun bahkan sudah dewasa pun juga mengakibatkan hubungan persusuan.

\section{DAFTAR KEPUSTAKAAN}

Abd. Kholid. 2007. Kuliyah Sejarah Perkembangan Kitab Tafsir. Surabaya: Fak. Ushuluddin.

Al-Alusiy, Mahmud. t. Th. Ruh al-Mu'aniy fi Tafsir al-Quran al-Adhim wa al-Sab'i al-Masaniy. Vol. IV. Bairut: Dar Ihya' al-Turas al-Arabiy.

Al-Farmawi, Abd al-Hayy. 1977. alBidayah fi al-Tafsir al-Maudu'i. Maktabah al-Hadarah al-Arabiyah. Kairo.

Al-Zuhaili, Wahbah. 2009. al-Tafsir fi alShari'ah wa al-Aqidah wa al-Manhaj. Vol II. Damaskus: Dar al-Fikr.

Baidan, Nashruddin. 2000. Metodologi Penafsiran al-Qur'an. Yogyakarta: Pustaka Pelajar, 
Husain al-Dzahabi, Muhammad. T.th. atTafsir wa al-Mufassirun. Juz I. Kairo: Dar al-Kutub alHaditsah.

Ibn Ahmad al-Ghazziy al-Hanafiy alTamartasyiy, Muhammad Ibn Abdillah, Tanwir al-Abshar wa Jami al-Bihar dalam Muhammad ibn Ali al-Hanafiy. 2002. Al-Durr al-Mukhtar. Bairut: Dar al-Kutub al-Ilmiyyah.

Ibn Jarir al-Thabariy, Muhammad, Jami' al-Bayan an Ta'wil Ay al-Quran. vol. VI, Al-Qahirah: Markaz al-Buhus wa
al-Dirasat al-Arbaiyyah, 1422 H/2001 Nashruddin Baidan. 1998. Metodologi Penafsiran al-Qur'an. Jakarta: Pustaka Pelajar.

Ibn Umar al-Raziy, Muhammad. 2002. Mafatih al-Ghaib. Vol. X .Bairut: Dar al-Fikr.

Ibnu Muhammad al-Dardir, Ahmad. 1999. Al-Syarh al-Shigar 'ala Aqrab alMasalik. Vol. II. Bairut: Dar al-Kutub al-Imiyyah. 